\title{
THE INTRODUCTION OF SCOLIA MANILAE ASHM. INTO THE HAWAIIAN ISLANDS.
}

By F. Murr, Hawaiian Sugar Planters' Association.

In July, 1912, the presence of Anomala orientalis (Waterhouse) was first recognized in the Hawaiian Islands, where it was found injuring the roots of sugar-cane. There are reasons to believe that it was introduced into the archipelago, probably in the soil of potted plants from Japan, more than four years before its presence was discovered. Although in 1912 it was confined to a comparatively small area, yet it was too widely spread to hope to exterminate it by drastic measures. As the use of insecticides did not prove any more successful here than elsewhere, it was decided to try and introduce insect enemies known to attack Scarabaeidæ in other parts of the world.

In judging of the probable utility of such enemies, it must be borne in mind that the biological environments of the Hawaiian Islands are very unique. Although the native insect fauna is rich in species of several groups, there are several large groups totally unrepresented. The whole of the great complex of the Lamellicornia is only represented by a single genus of Lucanidæ (Apterocychus) with a few allied species confined to Kauai, the most isolated and north westerly Island of the group. Of the enormous family of Scarabaeidæ not a single species is native, and there are good reasons to believe that the few species that are present have been introduced since the advent of the white man. Adoretus tenuimaculatus Waterhouse (known locally as the Japanese or rose beetle) was introduced from the Orient about 1896 and is one of the worst garden pests in the Islands, making the growing of roses in the lower and dryer districts very difficult, and spoiling the looks of many of the ornamental shrubs, on account of the ravages of the adult insect. The natural corollary of these conditions is the total absence of all the natural specific enemies of the Scarabaeidæ, such as Scolia, Tiphia, Presena, etc., which play an important part in keeping these beetles in check in other parts of the world; also the absence of those Mutilids, Bombyliids, Rhipiphorids, etc., which are known to attack the above parasites. It is this simplicity of biological environments 
that has, above everything else, made the controlling of certain insect pests by introduced insect parasites the success that it is.

Early in 1913 one of the members of the H. S. P. A. Experiment Station proceeded to Japan and eventually to Formosa, Java and the Philippines, to study the death factors of Anomala, Adoretus and allied "white grubs." The work is still in progress but as this is the first record of the successful introduction and establishment of a Scolia in a new region a brief statement of the establishment of Scolia manile Ashm. in Hawaii may be of interest to others working on similar problems.

This insect was described by Ashmead from specimens collected by Father Brown in the Observatory Gardens in Manila. It is very common in the grounds of the College of Agriculture at Los Banos, some forty miles from Manila, and it was here that most of our work was done. The Dean of the College very kindly placed the college insectary at our disposal and assisted us in every possible way.

After experimenting with different methods of handling the parasite we eventually adopted the following methods: A small quantity of soil was placed in the bottom of a small jelly jar with a tin cover, two Anomala or Adoretus grubs were placed in the soil, a twig of Alternanthera versicolor sprinkled with water and a few drops of honey was stuck in the soil and a female Scolia, caught in the field, was placed in the jar. After twentyfour hours the jars were turned out and each grub which bore an egg was placed in an artificial mud cell and the entrance closed with mud; the cells were packed in moist soil in tins with tight-fitting lids, and the tins in wicker baskets or boxes were shipped from Manila to Honolulu. By the time that they reached Honolulu the Scolias had pupated, and the cocoons were then placed in damp moss and the adults, when hatched, mated in captivity; a certain proportion were turned out in the field and a proportion retained for breeding. The mating was easily accomplished by confining a female in a sleeve-cage with a number of males and placing the cage in the sun. When shipping by direct or fast boats no Scolia hatched out during the voyage, but by more circuitous routes or by slow boats, a larger or smaller percentage would hatch out and die. On an average, sixty per cent. of the eggs placed in cells went through 
to pupæ. For a time we tried placing the cocoons in glass tubes packed in moss, but this method of shipment was not so successful.

The length of the life cycle varied considerably. In Los Banos the average was about 40 days, shortening by a week or ten days under favorable conditions in the summer and lengthening to two months or more in the dry winter months. A similar variation takes place in Honolulu, some specimens having been three months in the cocoon. Small differences of temperature and moisture appear to effect them, especially in the resting larval or early pupal stages.

On one occasion a consignment of adult Scolias and Tiphias was brought over in a cage with growing Alternanthera, but this method could only be used successfully when the cage was accompanied by some qualified person, as the insects require proper attention as to moisture and food.

Between December, 1915 and January, 1917, 6,578 eggs, pupæ and adult Scolias were shipped from Manila and 1191 living females and 973 living males arrived or hatched in Honolulu. Of 1691 cocoons shipped in glass tubes or moss 101 females and 54 males hatched in Honolulu; of 3884 eggs sent in mud cells, 1057 females and 908 males hatched out in Honolulu. These figures do not include those that issued during the voyage and died.

On March 13, 1916, one hundred and fifty cocoons received from Manila were buried in a field where Anomala larvæ were abundant. Subsequently those were dug up and it was found that thirteen adults had issued. August 2, 1916, one female and six males and on September 9 sixteen females and twenty-two males were liberated in the same locality. On September 16, the insects were found flying about in numbers that clearly indicated that they had become well established and were increasing rapidly. In January, 1917, they were so numerous in this locality that it was possible to catch as many as 175 females in one morning, and as many as 1606 females were caught during seventeen visits of a couple of hours each, and no diminution was observed, as more were caught on the last day than on the first. These were used to colonize other localities. If males had also been taken, six or seven times this number could have been caught. In other localities where colonies were liberated the Scolia is now known to be established. 
It will not be possible to estimate the ultimate effect of this parasite upon the Anomala problem before the end of the present year, but the prospects are good. As Scolia manila attacks Adoretus as well as Anomala, we hope that it will be beneficial in our gardens as well as in our cane fields.

During the course of this work we have experimented with several species of Tiphias, two species of Prosena, a Dexia, and a Campylotheca, also with several predators. Up to the present we have not succeeded in establishing any of these in Hawaii. In Japan there is a species of Asilid fly which is very active in the larval stage, attacking the larvæ of Anomala, and in the adult stage attacking the adult beetle, but we have had to eliminate this from our work as it is also very active against bees.

Bacteria acting upon the grubs have been found in all the countries in which we have carried on our work and it plays an important part in keeping a check upon Lamellicorn grubs. In Hawaii it has been noticed, and I have similar experience elsewhere, that a field badly infected with Anomala grubs will recover and be comparatively free for a period, and the writer has reasons to suspect that in some cases this is due to the accumulated bacteria in the soil making it too unhealthy for the grubs.

Fungus is also very effective in wet districts, and in dry districts during the wetter season.

Efforts were made to find an egg parasite and many thousand of eggs were placed in various situations, but without results. Ants and terminates attacked the eggs as well as the usual coleopterous predators.

After three years study of the death factors acting upon these beetles in Japan, Formosa, Java and the Philippine Islands the writer concludes that the problem is a complex one. The death rate is far highest among the eggs and larvæ and natural selection has been a small percentage to act upon in the adult stage, and the specific characters of these beetles show little or no effect of natural selection. 


\section{$2 \mathrm{BHL}$ Biodiversity Heritage Library}

Muir, F. 1917. "The Introduction of Scolia Manilae Ashm. into the Hawaiian Islands." Annals of the Entomological Society of America 10, 207-210. https://doi.org/10.1093/aesa/10.2.207.

View This Item Online: https://www.biodiversitylibrary.org/item/43648

DOI: https://doi.org/10.1093/aesa/10.2.207

Permalink: https://www.biodiversitylibrary.org/partpdf/193661

\section{Holding Institution}

Smithsonian Libraries

\section{Sponsored by}

Smithsonian

\section{Copyright \& Reuse}

Copyright Status: NOT_IN_COPYRIGHT

This document was created from content at the Biodiversity Heritage Library, the world's largest open access digital library for biodiversity literature and archives. Visit BHL at https://www.biodiversitylibrary.org. 